УДК 336.226

DOI: https://doi.org/10.37320/2415-3583/16.16

Чижова T.B.

кандидат економічних наук, доцент кафедри фінансів, банківської справи та страхування Херсонський національний технічний університет ORCID: https://orcid.org/0000-0002-6421-9461

\title{
ФІСКАЛЬНА СПРОМОЖНІСТЬ НЕПРЯМИХ ПОДАТКІВ В УМОВАХ ТІНЬОВОЇ ЕКОНОМІКИ
}

\begin{abstract}
Зростання тіньової економіки останнім часом спонукає уряди всіх краӥн шукати ефективні інструменти боротьби із ичм явищем. Точне визначення тіньової економіки дати досить складно, тому що тіньова економіка постійно розвивається, пристосовуючись до тих змін, які відбувається як в економіці, так $і$ в суспільстві. Тінізачія економіки значною мірою впливає на економічні процеси, як наслідок, держава втрачає надмірну кількість грошових ресурсів, які не надходять до державного бюджету у вигляді податкових надходжень. Саме непрямі податки в умовах зростаючої тіньової економіки виступають інструментом злочинних схем. Оскільки ухилення від сплати податків сьогодні є найбільшим компонентом дефіциту ПДВ, необхідно визначити, якою мірою можна збільшити надходження від ПДВ за рахунок забезпечення більш ефективного збору податків у середньостроковій і довгостроковій перспективі за інших рівних умов.
\end{abstract}

Ключові слова: тіньова економіка, податкова система, фіскальна ефективність, державний бюджет, податкові надходження, непрямі податки, ухилення від оподаткування.

Постановка проблеми. Сьогодні тіньова економіка $\epsilon$ актуальною проблемою як для всього світу, так і для України. Вона залишається однією 3 найсуттєвіших загроз економічній безпеці держави, що загострює соціально-економічну кризу в Україні та негативно позначається на іiі міжнародному іміджі. Саме тому розроблення ефективних механізмів детінізації сфери господарювання та фінансів, розшуку й повернення до легального обігу незаконно виведених із нього активів, захист об'єктів права власності є пріоритетними напрямами реалізації державної політики в правоохоронній галузі.

Аналіз останніх досліджень і публікацій. Дослідженню тіньових процесів в економічній діяльності присвячено праці багатьох учених. Зокрема, проблемами оцінки обсягів тіньової економіки та пошуку шляхів протидії займалися провідні вітчизняні вчені: В. Базилевич, 3. Варналій, А. Крисоватий, Ю. Крупка, В. Мандибура, Ю. Пасічник, О. Турчинов та ін. Серед зарубіжних науковців, які займалися дослідженням тінізації фінансових потоків, можна назвати таких науковців, як С. Бейкер, Ж. Тіроль, Ф. Когдан, О. Кауфман, $\Phi$. Шнайдер та ін.

Тіньова економіка - це явище, яке має довгу історію та глибоке коріння. Протягом не одного тисячоліття вчені намагалися вивчити кількісні та якісні боки цього явища. Розвиток суспільства, економічних відносин, вільного підприємництва неминуче сприяє тіньовій діловій активності у різноманітних іiі проявах. Із проблемами зростання рівня тінізації стикаються майже всі країни світу. Для міцних економік іiі обсяги фіксуються на рівні, що не має значного впливу на економіку, а для зростаючих - $є$ свідченням існування відтворювальної системи тіньових економічних відносин.

Мета статті полягає у дослідженні впливу рівня тіньової ефективності на стан надходження непрямих податків та визначенні основних пріоритетних напрямів детінізації економіки.
Виклад основного матеріалу. Ситуація, яка склалася в Україні, свідчить, що 26,2\% обсягу готівкової тіньової економіки (це 5,3\% ВВП, або 190 млрд грн) це «наслідкова тіньова економіка», за якої і продавець, і покупець виступають ініціаторами розрахунку готівкою. Решта $(73,8 \%)$ загального обсягу української тіньової економіки (або 14,4\% ВВП - 512 млрд грн) це «пасивна тіньова економіка», ініціатором якої виступає продавець [4].

Рівень тіньової економіки суттєво впливає на обсяг і структуру ВВП, тому це призводить до спотворення реальної картини що до його величини.

Тіньова економіка створює реальну загрозу як національній безпеці, так і демократичному розвитку держави. Рівень тінізації економіки негативно впливає на імідж країни, її конкурентоспроможність та зацікавленість у потужних інвестиціях.

Проблема рівня тінізації економіки є однією з передумов ефективної реалізації податкової політики держави.

Правопорушення в системі оподаткування виділяються високим професійним рівнем залучених фахівців, привабливим рівнем заробітної плати членів злочинних груп, досвідом поєднання легальної та нелегальної діяльності. Тіньові схеми передусім застосовуються у фінансово-кредитній системі, зовнішньоекономічній діяльності, паливно-енергетичному комплексі, у виробництві та реалізації підакцизної продукції. Шляхи тінізації діяльності та уникнення податкових зобов'язань вибираються залежно від виду податку, а також від часу, за який можна прокрутити злочинну схему. До найістотніших чинників тінізації національної економіки належать:

1. Малоефективне державне регулювання економіки - відсутність партнерських взаємовідносин між бізнесом і державою, високий рівень бюрократизму, недосконалість інституційного та законодавчого забезпечення. Із цього виникає проблема формування корпоративно-бюрократичних структур, які фактично підміняють собою механізм державного управління. 
2. Часта зміна законодавства в частині організації та ведення підприємницької діяльності, що унеможливлює ефективно планувати діяльність бізнесу та сприяє постійному пошуку шляхів до тінізації діяльності.

3. Неефективна система адміністрування податків, за якої бізнесу необхідно постійно лавірувати в законодавчому просторі й оптимізувати діяльність під впливом постійних змін як зовнішніх, так і внутрішніх чинників.

4. Відсутність ефективних та дієвих механізмів покарання за недотримання податкового законодавства, що створює додаткові стимули до мінімізації та ухилення від сплати податкових зобов'язань.

5. Рівень ринку праці, пов'язаний із низькими економічними стимулами до офіційного працевлаштування працівників та зростанням рівня безробіття. Великою проблемою є відсутність ефективної системи контролю та покарання за неофіційне працевлаштування та неоподаткування заробітної плати.

6. Недосконалість бюджетної ланки, низький контроль над прозорістю використанням бюджетних ресурсів.

7. Низькій рівень довіри до судової та правоохоронної системи завдяки їх недосконалості.

8. Високий рівень загальної злочинності.

На підставі аналізу наукової літератури з проблематики розвитку тіньової економіки доцільно виділити такі негативні наслідки:

1. Утрата податкових надходжень до бюджетів:

- деформація податкової системи;

- деформація структури державного бюджету;
- ускладнення виконання державою своїх фінансових зобов'язань;

- інфляційні процеси.

2. Викривлення основних макроекономічних показників:

- неефективність макроекономічної політики;

- недієвість управлінських рішень як на рівні держави, так і на рівні підприємства.

3. Руйнація системи соціально-економічних відносин у країні:

- деформація конкурентних відносин;

- деформація структури споживання;

- непрозорий та несправедливий розподіл національного доходу;

- криміналізація суспільства, у тому числі державного сектору.

4. Зменшення інтересу потенційних інвесторів [3].

Із фіскального погляду функціонування тіньової економіки в країні є досить негативним явищем. Це зумовлено тим, що доходи суб'єктів господарювання у тіньовому секторі не реєструються на державному рівні, а отже, не оподатковуються. Ухилення від оподаткування здійснюється економічними суб'єктами різними способами: використанням корумпованого складника в системі контролюючих органів, створенням різних фіктивних схем, у тому числі реєстрація бізнесу в офшорних зонах, та ін. Фіскальним наслідком такого ухилення $€$ фактичне зниження доходів бюджетів усіх рівнів, яке призводить до негативного впливу на вітчизняну економіку загалом. Отже, міні-

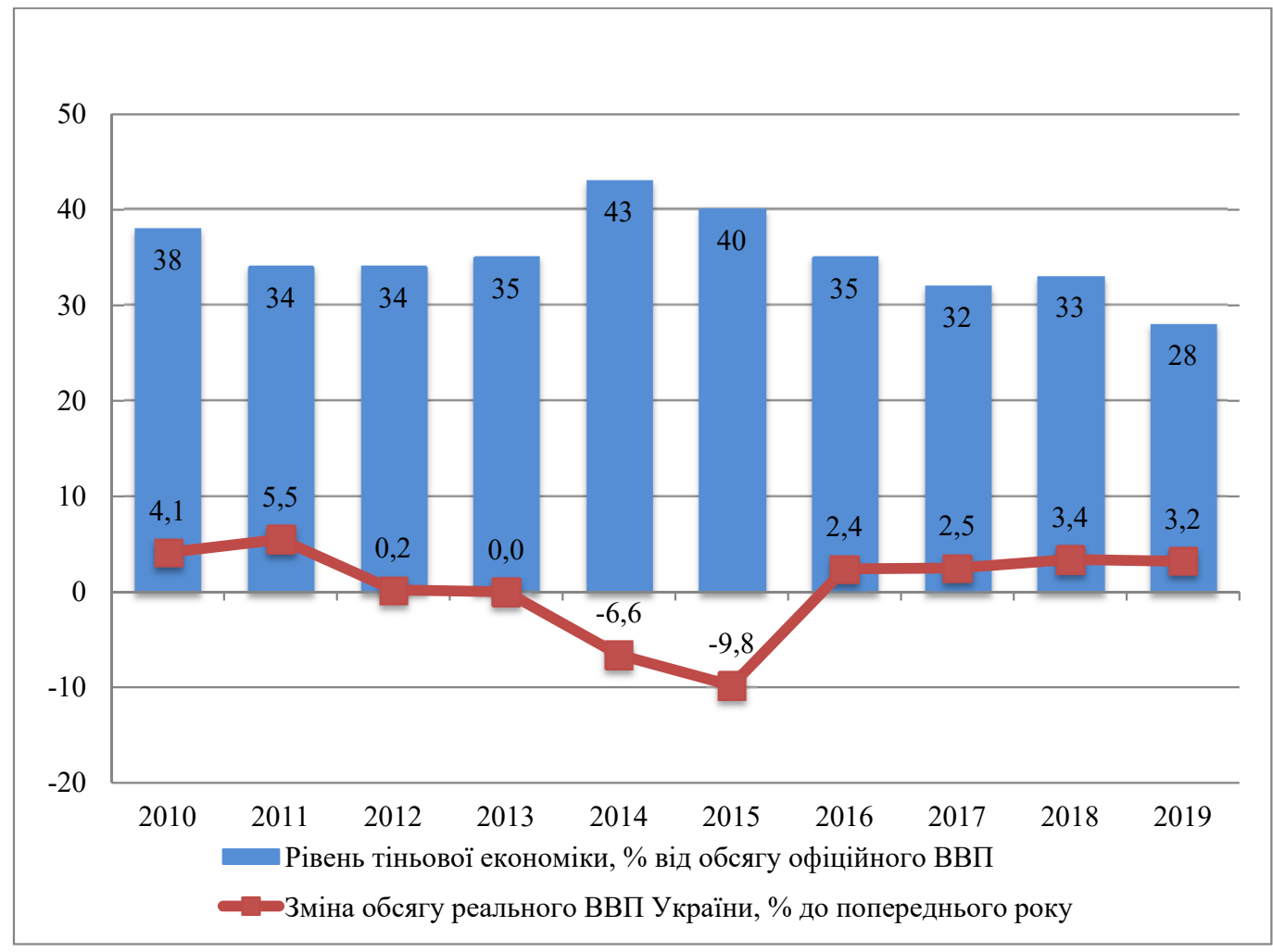

Рисунок 1 - Інтегральний показник рівня тіньової економіки в Україні (у \% від обсягу офіційного ВВП) і темпи приросту/зниження рівня реального ВВП (у \% до попереднього року).

Джерело: складено за даними [4] 
мізація доходів економічними суб'єктами шляхом ухилення від оподаткування має низку макроекономічних наслідків [2, с. 47].

Рівень тіньової економіки в 2019 р. становив 28\% від обсягу офіційного ВВП, що на 3 в. п. менше за показник 2018 р. На рис. 1 спостерігаємо тенденцію щодо рівня тіньової економіки на протязі 2010-2019 рр.

Починаючи 3 максимально високого рівня тіньової економіки в 2014 р. йде тенденція до поступового зниження. Однак залишається неподоланою низка чинників, що стримують процеси детінізації економіки в Україні.

Зазначений показник розраховується різними методами, які враховують розбіжності між доходами та витратами населення, динамікою готівки в обігу та обсягами виробництва, використанням електроенергії та обсягами виробництва, а також динамікою цін факторів виробництва, готової продукції та рентабельністю виробництва.

Методи, за якими здійснюється оцінка рівня тіньової економіки, зафіксували зменшення тінізації в 2019 р. порівняно з 2018 р. (рис. 2).

Метод збитковості підприємств та метод «витрати населення - роздрібний товарообіг» показали зменшення рівня тіньової економіки на 3 в. п. кожний і становили відповідно 17\% та 43\% від обсягу офіційного ВВП; монетарний метод зафіксував зменшення рівня тіньової економіки на 2 в. П. (до $22 \%$ від обсягу офіційного ВВП); за електричним методом рівень тіньової економіки зменшився на 1 в. п. (до 26\% від обсягу офіційного ВВП) [4].

Непрямі податки є вагомим джерелом наповнення бюджету. У доходах державного бюджету Укра- їни переважають саме непрямі податки: їх поступове щорічне збільшення за аналізований період становить у середньому 70 млрд грн. Вони здійснюють розподіл та перерозподіл доходів між різними соціальними групами населення [10, с. 46].

Водночас непрямі податки вважаються одними 3 найважливіших і найскладніших податків, що існують у вітчизняній податковій системі, тому детальний аналіз їх адміністрування та надходження до бюджету має велике значення як для платників податків, так і для держави в особі іiі виконавчих органів.

Однак в умовах зростаючої тіньової економіки саме ці податки виступають інструментом злочинних схем. Тіньова економіка постійно змінюється та адаптується під впливом глобалізації. Зокрема, зміни у способах роботи та бізнес-моделях, зростання цифрової економіки, більш широкі соціальні зміни спричиняють нові види діяльності тіньової економіки.

Оскільки ухилення від сплати податків сьогодні є найбільшим компонентом дефіциту ПДВ, необхідно поставити запитання, якою мірою можна збільшити надходження від ПДВ за рахунок забезпечення більш ефективного збору податків в середньостроковій і довгостроковій перспективі за інших рівних умов [11, с. 96].

Розглянемо структуру доходів державного бюджету України протягом 2014-2019 рр. (табл. 1).

У 2015 р. - 409,4 млрд грн, або 77,2\%, у 2016 р. 503,9 млрд грн, або 82,8\%, у 2017 р. - 627,1 млрд грн, або 82,8\%, у 2018 р. - 753,8 млрд грн, або 82,0\%, у 2019 р. - 799,8 млрд грн, або 80,9\% від усіх доходів.

Неподаткові надходження формують близько 20\% усіх доходів державного бюджету України. У 2015 р.

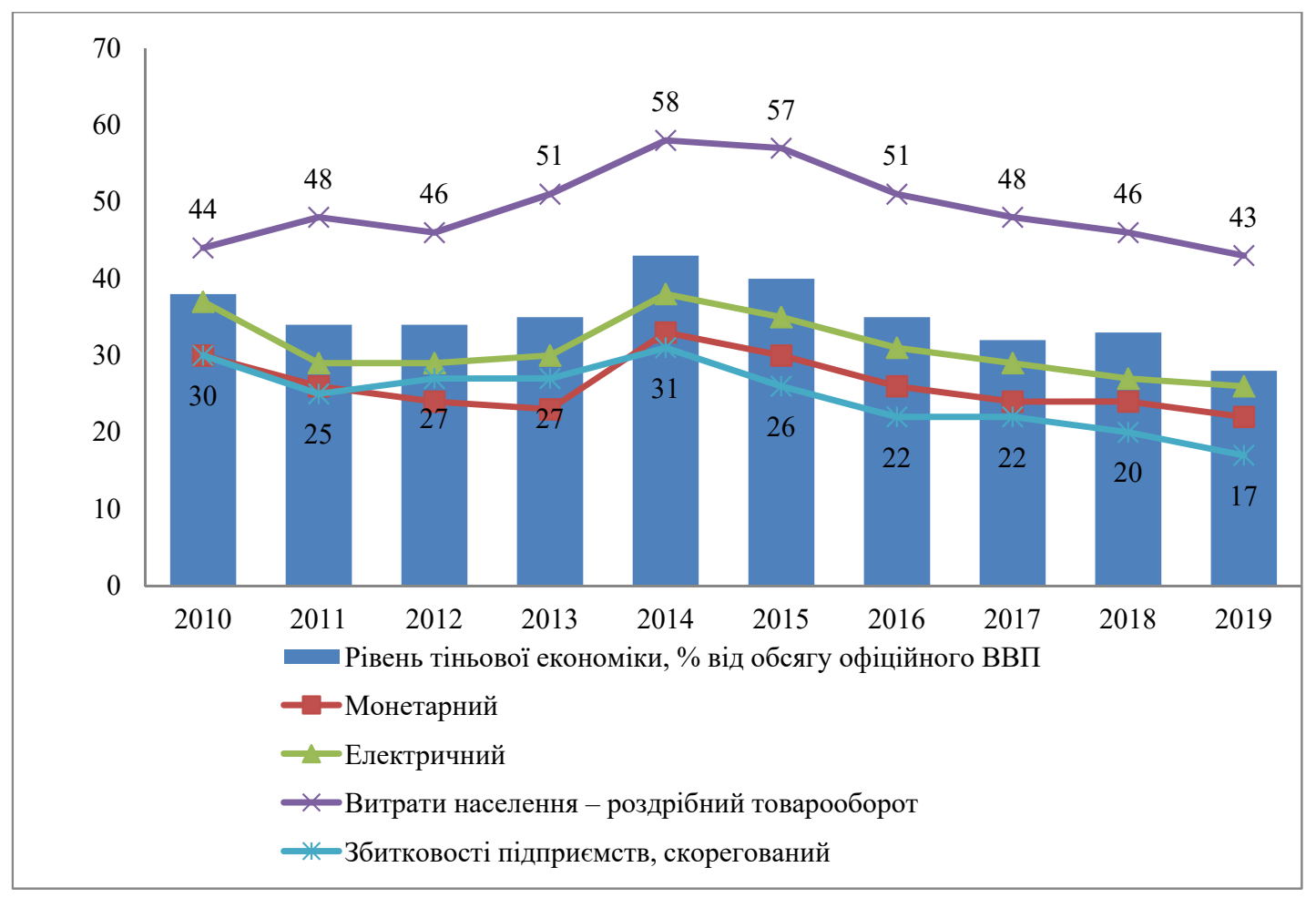

Рисунок 2 - Динаміка рівня тіньової економіки за окремими методами, \% від обсягу офіційного ВВП 
неподаткові надходження були на рівні 120,0 млрд грн, або $22,6 \%$, у 2016 р. - 103,6 млрд грн, або 17,0\%, у 2017 р. надходження неподаткових доходів становили 128,6 млрд грн, або ті ж 17\%, як у попередньому році, у 2018 та 2019 рр. також спостерігаємо тенденцію збільшення неподаткових надходжень, а саме 164,7 млрд грн, або 17,8\%, та 186,7 млрд грн, або 18,9\%, відповідно.

Незначний рівень доходу спостерігається 3 надходжень від операцій із капіталу, а саме у 2015 р. 0,2 млрд грн, або 0,1\%, у 2016 р. - 0,2 млрд грн, або 0,1\%, у 2017 р. показники залишися на рівні попереднього року, у 2018 р. - 0,7 млрд грн, або 0,1\%, у 2019 р. - 0,2 млрд грн, або 0,1\%.

Найменшим показником доходу державного бюджету України є надходження від цільових фондів, а саме: у 2015 р. надходження становили 0,2 млрд грн, або 0,1\%, у 2016 р. - 0,3 млрд грн, або 0,1\%, у 2017 р. 0,1 млрд грн, або $0,1 \%$, а в 2018 р. - 0,2 млрд грн, або $0,1 \%$. У 2019 р. надходження дещо зросли і становили 1,8 млрд грн, або $0,1 \%$ усіх надходжень.

Аналіз формування дохідної частини державного бюджету показав, що існує тенденція прирощення податкових доходів державного бюджету. Проте цей приріст не має твердого підгрунтя у зв'язку з тим, що в Україні протягом останніх років нестабільна економічна ситуація, зокрема недосконала податкова політика.

Починаючи з січня 2019 р. відбулося вповільнення темпів зростання ВВП, що, своєю чергою, позначилося на бюджеті. Протягом року низка чинників вплинула i на рівень податкових надходжень, що й визначили долю кошторису. Доходи бюджету становили 998,2 млрд грн, що на 37,9 млрд грн менше запланованих. Недоотримання бюджетом коштів могло бути більшим, якби Нацбанк України не переказав на 17,3 млрд грн більше свого чистого прибутку, а «Нафтогаз» не сплатив би достроково 15,1 млрд грн дивідендів та податків.

Зазначимо, що система державного оподаткування повинна не просто залучати частину вартості внутрішнього національного продукту на формування доходів Державного бюджету, а й активно впливати на підвищення ефективності суспільного виробництва, заохочувати окремого виробника, господарюючі суб'єкти до інвестування коштів у різні галузі діяльності $[10$, c. 46$]$.

Розглянемо детальніше структуру надходжень непрямих податків до державного бюджету протягом 2015-2019 pр. (табл. 2).

ПДВ є найбільшим бюджетоутворюючим показником. Із 2015 по 2019 р. його частка становила у середньому $68,8 \%$.

у 2015 p. надходження ПДВ становили 178,4 млрд грн, а частка становила $63,3 \%$, у 2016 р. також спостерігаємо збільшення надходжень цього податку, а саме 226 млрд грн, або 67,2\%. У 2017 та 2018 рр. надходження становили 314,0 та 374,5 млрд грн відповідно, або 70,3\% та 72,0\%. У 2019 р. надходження ПДВ дещо збільшилися і становили 378,7 млрд грн, або 71,3\% надходжень усіх непрямих податків.

Також вагоме місце серед непрямих податків посідає акцизний податок, його надходження у 2015 році становили 63,1 млрд грн, або 22,4\%, із кожним роком спостерігаємо приріст надходжень в абсолютному значенні, але за структурою простежуються зміни і коли-

Таблиця 1 - Структура доходів державного бюджету України протягом 2015-2019 рр.

\begin{tabular}{|c|c|c|c|c|c|c|c|c|c|c|}
\hline \multirow[b]{2}{*}{ Показники } & \multicolumn{2}{|c|}{2015 рік } & \multicolumn{2}{|c|}{2016 рік } & \multicolumn{2}{|c|}{2017 рік } & \multicolumn{2}{|c|}{2018 рік } & \multicolumn{2}{|c|}{2019 рік } \\
\hline & млрд грн & \begin{tabular}{|l|} 
питома \\
вага, \%
\end{tabular} & млрд грн & $\begin{array}{l}\text { питома } \\
\text { вага, \% }\end{array}$ & млрд грн & $\begin{array}{l}\text { питома } \\
\text { вага, \% }\end{array}$ & млрд грн & $\begin{array}{l}\text { питома } \\
\text { вага, \% }\end{array}$ & млрд грн & $\begin{array}{l}\text { питома } \\
\text { вага,\% }\end{array}$ \\
\hline $\begin{array}{l}\text { Податкові } \\
\text { надходження }\end{array}$ & 409,4 & 77,2 & 503,9 & 82,8 & 627,1 & 82,8 & 753,8 & 82,0 & 799,8 & 80,9 \\
\hline $\begin{array}{l}\text { Неподаткові } \\
\text { надходження }\end{array}$ & 120 & 22,6 & 103,6 & 17,0 & 128,6 & 17,0 & 164,7 & 17,8 & 186,7 & 18,9 \\
\hline $\begin{array}{l}\text { Доходи від } \\
\text { операцій } 3 \\
\text { капіталом } \\
\end{array}$ & 0,2 & 0,1 & 0,2 & 0,1 & 0,2 & 0,1 & 0,7 & 0,1 & 0,2 & 0,1 \\
\hline Цільові фонди & 0,2 & 0,1 & 0,3 & 0,1 & 0,1 & 0,1 & 0,2 & 0,1 & 1,8 & 0,1 \\
\hline Всього & 529,8 & 100 & 608,0 & 100 & 756 & 100,0 & 919,4 & 100 & 988,5 & 100 \\
\hline
\end{tabular}

Джерело: складено автором за даними [9]

Таблиця 2 - Структура надходжень непрямих податків до державного бюджету України протягом 2015-2019 рр.

\begin{tabular}{|c|c|c|c|c|c|c|c|c|c|c|}
\hline \multirow[b]{2}{*}{ Показники } & \multicolumn{2}{|c|}{2015 рік } & \multicolumn{2}{|c|}{2016 рік } & \multicolumn{2}{|c|}{2017 рік } & \multicolumn{2}{|c|}{2018 рік } & \multicolumn{2}{|c|}{2019 рік } \\
\hline & млрд грн & $\begin{array}{l}\text { питома } \\
\text { вага, \% }\end{array}$ & млрд грн & $\begin{array}{l}\text { питома } \\
\text { вага, \% }\end{array}$ & $\begin{array}{l}\text { питома } \\
\text { вага, \% }\end{array}$ & млрд грн & $\begin{array}{l}\text { питома } \\
\text { вага, \% }\end{array}$ & млрд грн & $\begin{array}{l}\text { питома } \\
\text { вага,\% }\end{array}$ & млрд грн \\
\hline ПДВ & 178,4 & 63,3 & 226,0 & 67,2 & 314 & 70,3 & 374,5 & 72,0 & 378,7 & 71,3 \\
\hline $\begin{array}{l}\text { Акцизний } \\
\text { податок }\end{array}$ & 63,1 & 22,4 & 90,1 & 26,8 & 108,3 & 24,2 & 118,9 & 22,8 & 122,4 & 23,0 \\
\hline Мито & 40,3 & 14,3 & 20,4 & 6,0 & 24,5 & 5,5 & 27 & 5,2 & 30,1 & 5,7 \\
\hline $\begin{array}{l}\text { Всього } \\
\text { непрямих } \\
\text { податків }\end{array}$ & 281,8 & 100,0 & 336,5 & 100,0 & 446,8 & 100,0 & 520,4 & 100,0 & 531,2 & 100,0 \\
\hline
\end{tabular}




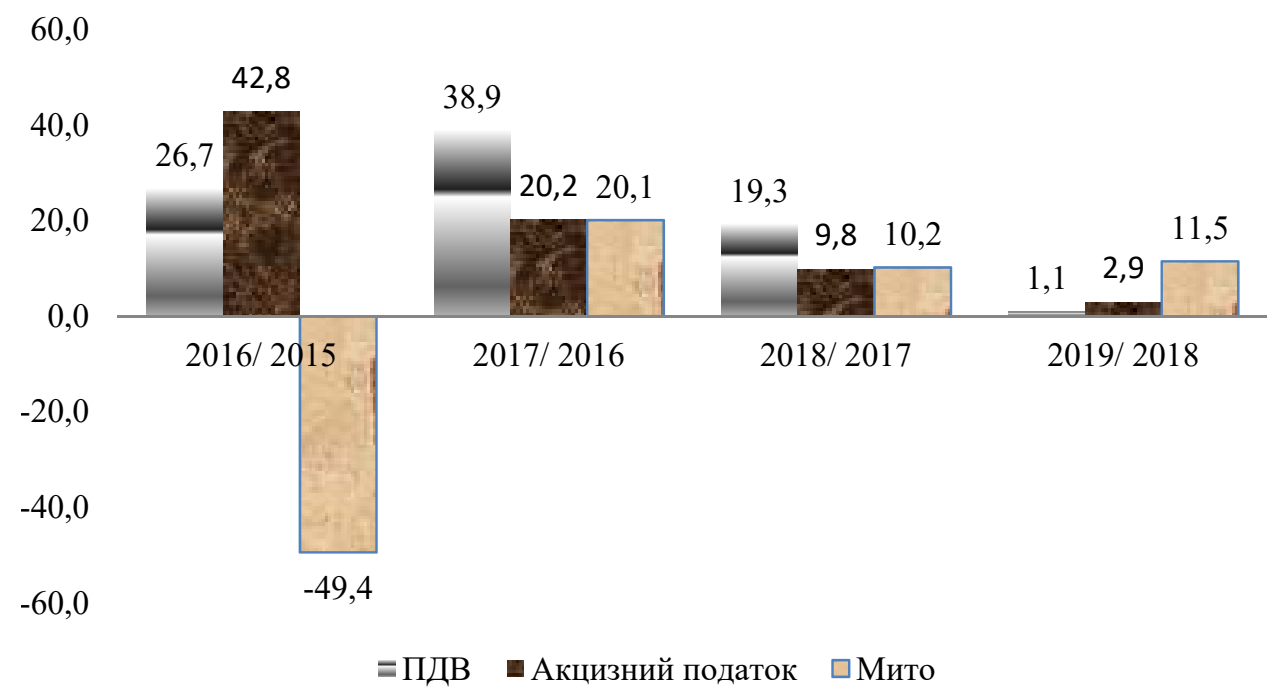

Рисунок 3 - Динаміка темпів приросту надходжень непрямих податків до державного бюджету України за 2015-2019 рр., \% [9]

вання, а в 2019 р. його надходження становили вже 122,4 млрд грн, або 23,0\%.

Серед непрямих податків найменше надходжень отримуємо від мита, їх надходження у 2015 р. становили 40,3 млрд грн, або 14,3\%. А в 2019 р. надходження вже становили 0,1 млрд грн, або 5,7\%.

Динаміку темпів приросту надходжень непрямих податків до державного бюджету України за 2015-2019 рр. представлено на рис. 3

На рис. 3 добре видно, що темпи росту за кожним показником із кожним роком збільшувалися, окрім надходження мита в 2016 р.

У формуванні доходів держави визначальну роль відіграє напрям адміністрування непрямих податків, оскільки саме завдяки йому забезпечується в середньому 40\% загальних доходів зведеного бюджету України [5].

Поглиблений аналіз у розрізі видів непрямих податків свідчить, що основним із них із позиції бюджетоутворення був податок на додану вартість. Загалом цей податок відіграє ключову роль у процесі формування доходів державного бюджету держави, оскільки є найменш схильним до кон'юнктурних коливань світових цін на сировину й енергоносії порівняно 3 іншими бюджетотвірними податками. При цьому він залишається одним із найпроблемніших податків у вітчизняній податковій системі.

В Україні досить гостро стоїть проблема адміністрування ПДВ. Під впливом реформування системи оподаткування бюджетоформуючий ПДВ змінився останніми роками на бюджетовитратний. У ході незаконного відшкодування ПДВ були створені умови для особливого різновиду кримінального бізнесу. Завдяки системі електронного адміністрування ПДВ із кожним роком отримати відшкодування ПДВ підприємствам усе важче, а межа за його повернення з боку податкових органів зростає. Протистояння між бізнесом i контролюючими органами триває: бізнес використовує двояке трактування у вітчизняному законодавстві і формує до відшкодування чималі суми даного податку.

Висновки. Сьогодні пріоритетного значення набувають процеси детінізації національної економіки у сфері протидії тінізації фінансових потоків, легалізації ринку праці та детінізації земельних відносин. Незважаючи на велику кількість різних методів дослідження економічної діяльності в тіньовому секторі економіки, не можна говорити про їх абсолютну достовірність, деякі 3 них морально застарілі, а інші потребують адаптації до сучасних умов, тому існує необхідність створення нових та подальше вдосконалення комплексу існуючих методик, де особливу увагу варто приділяти виявленню пріоритетних напрямів розрахунків, удосконаленню інформаційної бази, розробленню більш досконалої системи розрахунків, реформуванню процесу адміністрування непрямих податків та підвищенню якості контролю над правильністю нарахування та сплати податкових платежів.

\section{Список використаних джерел:}

1. Андрущенко В.Л., Тучак Т.В. Морально-етичні імперативи податків та оподаткування (західна традиція) : монографія. Київ : Алерта, 2013. 384 с.

2. Варналій 3.С. Теоретичні засади детінізації економіки України. Вісник Вінницького політехнічного інституту: економіка та менеджмент. 2014. № 1. С. 47-53.

3. Дадашова П.А., Кладова М.П. Вплив тіньової економіки на економічну безпеку України. Ефективна економіка. 2016. Вип. 11. URL: http://www.economy.nayka.com.ua/?op=1\&z=5271

4. Загальні тенденції тіньової економіки в Україні у 2019 році. URL: https://www.me.gov.ua/?lang-UA (дата звернення: 07.02.2021).

5. Крисоватий А.І., Томнюк Т.Л. Адміністрування податків в Україні: організація та напрями трансформації : монографія. Тернопіль : Економічна думка, 2012. 212 с.

6. Офіційний сайт Головного управління ДПС у Херсонській області. URL: https://kherson.tax.gov.ua/dfs-u-regioni/golovupr/kontakti-/ (дата звернення: 26.01.2021). 
7. Офіційний сайт Міністерства розвитку економіки, торгівлі та сільського господарства України. URL: https://www.me.gov.ua/ ?lang=uk-UA (дата звернення: 08.02.2021).

8. Податковий кодекс України : Закон України від 02.12.2010 № 2755- VI. URL: http://zakon3.rada.gov.ua/laws/ show/2755-17 (дата звернення: 05.02.2021).

9. Річний звіт про виконання державного бюджету за 2015-2019 роки. Офіційний сайт Державної казначейської служби України. URL: https:/www.treasury.gov.ua/ua/file-storage/vikonannya-derzhavnogo-byudzhetu (дата звернення: 28.01.2021).

10. Сідельникова Л.П. Ефективність податкових джерел формування бюджетних ресурсів держави. Фінанси України. 2015. № 9. С. $45-60$.

11. Чижова Т.В. Сучасні реалії адміністрування ПДВ та вирішення проблем його гармонізації. Вісник Бердянського університету менеджменту і бізнесу. 2011. № 1(13). С. 96-99.

\section{References:}

1. Andrushchenko V.L., Tuchak T.V. (2013) Moralno-etychni imperatyvy podatkiv ta opodatkuvannia (zakhidna tradytsiia) [Moral and ethical imperatives of taxes and taxation (Western tradition)]. Kyiv: Alerta. (in Ukrainian)

2. Varnalii Z.S. (2014) Teoretychni zasady detinizatsii ekonomiky Ukrainy [Theoretical principles of de-shadowing of Ukraine's economy]. Bulletin of Vinnytsia Polytechnic Institute: Economics and Management, no. 1, pp. 47-53.

3. Dadashova P.A., Kladova M.P. (2016) Vplyv tinovoi ekonomiky na ekonomichnu bezpeku Ukrainy [The impact of the shadow economy on the economic security of Ukraine]. Efficient economy, vol. 11. Available at: http://www.economy.nayka.com.ua/ ?op $=1 \& z=5271$ (accessed 07 February 2021).

4. Zahalni tendentsii tinovoi ekonomiky v Ukraini u 2019 rotsi [General trends of the shadow economy in Ukraine in 2019]. Available at: https://www.me.gov.ua/?lang=uk-UA (accessed 07 February 2021).

5. Krysovatyi A.I., Tomniuk T.L. (2012) Administruvannia podatkiv v Ukraini: orhanizatsiia ta napriamy transformatsii [Tax administration in Ukraine: organization and directions of transformation]. Ternopil: Economic Thought of TNEU. (in Ukrainian)

6. Ofitsiinyi sait Holovnoho upravlinnia DPS u Khersonskii oblasti [The official site of the Main Directorate of the STS in Kherson region]. Available at: https://kherson.tax.gov.ua/dfs-u-regioni/golov-upr/kontakti-/ (accessed 26 January 2021).

7. Ofitsiinyi veb-sait Ministerstva ekonomichnoho rozvytku ta silskoho hospodarstva Ukrainy [Official site of the Ministry of Economic Development, Trade and Agriculture of Ukraine]. Available at: https://www.me.gov.ua/?lang=uk-UA (accessed 08 February 2021).

8. Podatkovyi kodeks Ukrainy: Zakon Ukrainy vid 02.12.2010 № 2755 -VI [Tax Code of Ukraine: Law of Ukraine dated 27.12.2010 № 2755-VI]. Available at: http://zakon3.rada.gov.ua/laws/ show/2755-17 (accessed 16 January 2021).

9. Richnyi zvit pro vykonannia derzhavnoho biudzhetu za 2015-2019 roky. [Annual report on the implementation of the state budget for 2015-2019]. Official site of the State Treasury Service of Ukraine. Available at: https://www.treasury.gov.ua/ua/file-storage/ vikonannya-derzhavnogo-byudzhetu (accessed 10 January 2021).

10. Sidelnykova L.P. (2015) Efektyvnist podatkovykh dzherel formuvannia biudzhetnykh resursiv derzhavy [Efficiency of tax sources of formation of budgetary resources of the state]. Finance of Ukraine, no. 9, pp. 46-60.

11. Chyzhova T.V. (2011) Suchasni realii administruvannia PDV ta vyrishennia problem yoho harmonizatsii [Modern realities of VAT administration and solving the problems of its harmonization]. Bulletin of Berdyansk University of Management and Business: Science. economy. magazine, no. 1(13), pp. 96-99.

Chyzhova Tamila Kherson National Technical University

\section{FISCAL CAPACITY OF INDIRECT TAXES IN THE CONDITION OF SHADOW ECONOMY}

The recent growth of the shadow economy has prompted all countries' governments to look for effective tools to combat this phenomenon. The impact of the shadow economy on various aspects of state development is complex and requires detailed analysis. The shadow economy's exact definition is quite difficult because the shadow economy is constantly evolving, adapting to the changes taking place in both the economy and society. Factors that lead to increased shadowing include high crime rates, high bureaucratization, lack of an effective system of control and punishment for informal employment and non-taxation of wages, imperfect monetary regulation, inefficient tax administration, low control over the use of budget funds, inconsistencies, and duplication of the legal and regulatory framework, electronic trading systems and real estate networks. The shadowing of the economy significantly affects economic processes. As a result, the state loses an excessive amount of money that does not go to the state budget in tax revenues. It is indirect taxes in a growing shadow economy that are an instrument of criminal schemes. At the same time, indirect taxes are considered one of the most important and complex taxes in the domestic tax system. Therefore, a detailed analysis of their administration and budget revenues is important for taxpayers and the state represented by its executive bodies. An in-depth analysis in terms of indirect taxes shows that the main one from the standpoint of budgeting is the value added tax. In general, this tax plays a key role in generating state budget revenues, as it is the least prone to fluctuations in world prices for raw materials and energy compared to other budget-generating taxes. At the same time, it remains one of the most problematic taxes in the domestic tax system. As tax evasion is currently the largest component of the value added tax deficit, it is necessary to determine the extent to which value added tax revenues can be increased by ensuring more efficient tax collection in the medium and long term, other things being equal. Given the study, it can be argued that the improvement of the existing system of administration of indirect taxes will allow in the shadow economy to introduce mechanisms for withdrawing liquid assets from the shadows in order to deepen the fiscal function of indirect taxes.

Key words: shadow economy, tax system, fiscal efficiency, state budget, tax revenues, indirect taxes, tax evasion.

JEL classification: $\mathrm{H} 20, \mathrm{H} 26, \mathrm{H} 61, \mathrm{H} 71$ 